\title{
ЦЕЛЛЮЛОЛИТИЧЕСКИЕ БАКТЕРИИ И АССОЦИАЦИЯ ЭФФЕКТИВНЫХ МИКРООРГАНИЗМОВ ДЛЯ БИОКОНТРОЛЯ КОРНЕВЫХ ГНИЛЕЙ САХАРНОЙ СВЕКЛЫ (Beta vulgaris L.)*
}

\author{
И.Э. СМИРНОВА, А.К. САДАНОВ
}

В настоящее время многие хозяйства, производящие сахарную свеклу (Beta vulgaris L.), сокращают применение удобрений и не используют севообороты, что приводит к истощению почв, оскудению их микробоценоза и накоплению фитопатогенов, в частности грибов Fusarium Lk.:Fr. и Alternaria (Fr.) Keissi. Использование химических фунгицидов приводит к развитию устойчивости к ним у грибов, требующей увеличения дозы препаратов. В этой связи поиск микроорганизмов и разработка на их основе биопрепаратов для борьбы с патогенами растений становится все более актуальным. В представленной работе мы изучили антифунгальные свойства нового штамма целлюлолитических бактерий Bacillus sp. C-82/3 и создали с этим штаммом эффективную ассоциацию азотфиксирующих и фосфатмобилизующих бактерий, которая оказывает положительное действие на развитие и продуктивность растений сахарной свеклы. Нашей целью было выявление антифунгальных свойств целлюлолитических бактерий штамма Bacillus sp. C-82/3, его включение в состав ассоциации эффективных микроорганизмов (ЭМ-ассоциация) - Azotobacter chroococcum и Bacillus megaterium, оценка ростостимулирующей активности этой ЭМ-ассоциации и возможности ее применения для биоконтроля корневых гнилей и повышения продуктивности сахарной свеклы в полевых условиях. Штамм целлюлолитических бактерий Bacillus sp. C-82/3 был выделен из ризосферы здоровых растений сахарной свеклы на юго-востоке Казахстана (Жамбылская обл.). Антифунгальные свойства штамма С-82/3 изучали методом агаровых блоков в отношении основных возбудителей корневых гнилей сахарной свеклы: Alternaria alternata (Fr.) Keissl, Fusarium solani (Mart.) Sacc. и Fusarium oxysporum Schlecht. Штамм выращивали на среде Гетчинсона $\left(\mathrm{K}_{2} \mathrm{HPO}_{4}-1,0\right.$ г/л, $\mathrm{CaCl}_{2}-0,1$ г/л, $\mathrm{MgSO}_{4}-0,3$ г/л, $\mathrm{NaNO}_{3}-2,5$ г/л, $\mathrm{NaCl}-$ 1,0 г/л, $\mathrm{FeCl}_{3}-0,01$ г/л, пшеничная солома $-20,0$ г/л, дрожжевой экстракт $-5,0$ г/л, агар 20,0 г/л, рН 7,0) в течение 5 сут при температуре $28^{\circ} \mathrm{C}$, затем вырезали агаровые блоки, переносили на чашки Петри, предварительно засеянные культурами грибов, и инкубировали при $28{ }^{\circ} \mathrm{C}$ в течение 3 сут. Об антифунгальной активности судили по диаметру зоны подавления роста грибов. Для изучения стимуляции роста растений семена сахарной свеклы сорта Айсултан обрабатывали суспензией бактерий (штамм С-82/3 или ЭМ-ассоциация, содержащая этот штамм) с титром $1 \times 10^{7}$ кл/мл при температуре $23{ }^{\circ} \mathrm{C}$ в течение 2 ч. Через 30 сут выращивания в климатической камере (Constant Climate Chamber HPP750, «Memmert GmbH + Co. KG», Германия) у проростков измеряли длину стеблей и корней и сравнивали их с контролем (вода). Полевые опыты проводили в фермерском хозяйстве «Кайынды» (Жамбылская обл., Республика Казахстан) в 2017-2018 годах. Антифунгальная активность нового штамма C-82/3 в отношении грибов $F$. oxуsporum составляла $28,9 \pm 0,2$ мм, $F$. solani $-38,2 \pm 0,3$ мм, A. alternata $-46,6 \pm 0,9$ мм. Показана его биосовместимость со штаммами азотфиксирующих и фосфатмобилизующих бактерий, что позволило создать новую ЭМ-ассоциацию, обладающую антифунгальной активностью и положительно влияющую на продуктивность сахарной свеклы. Как штамм С-82/3, так и ЭМ-ассоциация, состоящая из трех штаммов бактерий (Bacillus megaterium, Azotobacter chroococcum и Bacillus sp. C-82/3), обладали высокой ростостимулирующей активностью: при выращивании в климатической камере всхожесть семян увеличивалась на 7-16\%, длина стеблей - в 1,2-1,5 раза, корней - в 1,1-2,0 раза по сравнению с контролем $(\mathrm{p} \leq \mathbf{0 , 0 5})$. В полевых опытах при обработке семян тестируемой бактериальной суспензией пораженность всходов сахарной свеклы коревыми гнилями снижалась в 2,3 раза, корнеплодов - в 3,0 раза, урожайность возрастала на $34,0 \pm 2,3$ ц/га по сравнению с контролем $(\mathbf{p} \leq \mathbf{0 , 0 5})$. Таким образом, нами установлена высокая антифунгальная активность нового штамма Bacillus sp. C-82/3 и впервые показана возможность использования ЭМ-ассоциации с этим штаммом для биоконтроля возбудителей корневых гнилей сахарной свеклы и повышения ее урожайности в полевых условиях.

Ключевые слова: Beta vulgaris L., сахарная свекла, биологический контроль, целлюлолитические бактерии, ЭМ-ассоциация, антифунгальная активность, ростостимулирующая активность, фитопатогенные грибы, корневая гниль.

Сахарная свекла (Beta vulgaris L.) - одна из основных технических культур. В мировом земледелии она занимает 7,913 млн га. В наибольшем

* Исследования проведены при финансовой поддержке Министерства образования и науки Республики Казахстан (грантовый проект № АР05131526). 
количестве сахарная свекла производится в России, за которой следуют Франция и США $(1,2)$. В то же время выращивание сахарной свеклы наносит существенный урон почвам, поскольку с урожаем выносится значительное количество питательных элементов, что вызывает сокращение почвенной микробной массы и ее биоразнообразия (3-5). Кроме того, многие свеклосеющие хозяйства не применяют ротацию культур: высевают сахарную свеклу на одних и тех же полях в течение 5-7 лет $(6,7)$. Все это приводит к накоплению фитопатогенов, вызывающих болезни, в основном корневые гнили (8-10). Потери урожая культуры из-за поражения корневыми гнилями в России достигают $30 \%$, в Казахстане - 20-40 \%, в Киргизии - 50 \% (11-14). В других странах корневые гнили также наносят существенной урон (30-35 \%) (15-17).

Современное сельское хозяйство характеризуется высокой степенью использования фунгицидов. Применение химических средств защиты растений создает определенные проблемы, причем негативное влияние фунгицидов со временем возрастает. Развивается устойчивость грибов к фунгицидам, требующая увеличения дозы препаратов (18-20). Из-за экологических нарушений все более острым становится вопрос о сокращении применения химических пестицидов. В качестве альтернативы выступают биологические методы защиты растений. Актуален поиск микроорганизмов и разработка на их основе биопрепаратов для борьбы с фитопатогенами растений (21-24).

В последнее время все чаще применяют ассоциации эффективных микроорганизмов (ЭМ-ассоциации), характеризующиеся более широким спектром биологической активности по сравнению с монокультурами микроорганизмов (25-27). В состав ЭМ-ассоциаций входят азотфиксирующие, фосфатмобилизующие, целлюлолитические, силикатные и другие микроорганизмы, которые обладают защитно-стимулирующим действием: синтезируют и поставляют растениям необходимые вещества (ферменты, витамины, аминокислоты), улучшают азотное и фосфорное питание, что приводит к повышению урожайности и улучшению качества продукции $(28,29)$. При этом значительно сокращается применение минеральных удобрений и химических средств защиты растений, конечная продукция становится экологически чистой и безопасной для человека (30-32).

Ранее нами была создана ассоциация микроорганизмов, состоящая из штаммов азотфиксирующих бактерий Azotobacter chroococcum и фосфатмобилизующих бактерий Bacillus megaterium, которая положительно влияла на продуктивность сахарной свеклы за счет улучшения азотного и фосфорного питания растений, но не обладала антифунгальной активностью.

Целлюлоза составляет основную массу растительных остатков в почве, в связи с чем целлюлолитические микроорганизмы относятся к важным компонентам микробоценозов и играют значительную роль в почвенных процессах $(33,34)$. Их содержание в почве служит показателем ее плодородия и экологического состояния (35). Способность целлюлолитических бактерий развиваться в ризосфере растений, синтезировать витамины группы В, аминокислоты и ферменты обеспечивает их высокую эффективность для биоконтроля патогенов растений $(36,37)$. Также среди целлюлолитических бактерий обнаружены активные антагонисты фитопатогенных грибов, вызывающих корневые гнили агрокультур (38, 39). В связи с этим представлялось перспективным включить в состав ЭМассоциации целлюлолитические бактерии.

В представленной работе были изучены антифунгальные свойства нового штамма целлюлолитических бактерий Bacillus sp. C-82/3 и впервые 
создана ЭМ-ассоциация азотфиксирующих и фосфатмобилизующих бактерий с этим штаммом. Было показано, что ЭМ-ассоциация улучшает азотное и фосфорное питание растений, характеризуется антифунгальной активностью и продуцирует биологически активные вещества, что оказывает положительное действие на развитие и продуктивность растений сахарной свеклы.

Нашей целью была оценка антифунгальных свойств целлюлолитического штамма Bacillus sp. C-82/3, его включение в состав ассоциации эффективных микроорганизмов, определение ростостимулирующей активности ЭМ-ассоциации и возможности ее применения для биоконтроля корневых гнилей и повышения продуктивности сахарной свеклы в полевых условиях.

Методика. Штамм целлюлолитических бактерий Bacillus sp. C-82/3 был выделен из ризосферы здоровых растений сахарной свеклы на юговостоке Казахстана (Жамбылская обл.). Штамм выращивали на среде Гетчинсона, следующего состава: $\mathrm{K}_{2} \mathrm{HPO}_{4}\left(1,0\right.$ г/л), $\mathrm{CaCl}_{2}\left(0,1\right.$ г/л), $\mathrm{MgSO}_{4}$ (0,3 г/л), $\mathrm{NaNO}_{3}(2,5$ г/л), $\mathrm{NaCl}$ (1,0 г/л), FeC1з (0,01 г/л), пшеничная солома $(20,0$ г/л), дрожжевой экстракт $(5,0)$, вода водопроводная (1 л). В качестве тест-культур при оценке антифунгальной активности Bacillus sp. C82/3 использовали три штамма фитопатогенных грибов - Alternaria alternata (Fr.) Keissl, Fusarium solani (Mart.) Sacc. и Fusarium oxysporum Schlecht, вызывающих корневые гнили сахарной свеклы (штаммы были любезно предоставлены сотрудниками ТОО НПЦ микробиологии и вирусологии). Эти грибы были проверены согласно принципам триады Коха и характеризовались высокой патогенностью.

Грибы культивировали на картофельно-декстрозном агаре (КДА) («Himedia», Индия) в течение 10 сут при $25{ }^{\circ} \mathrm{C}$ и хранили при $4{ }^{\circ} \mathrm{C}$. Антифунгальные свойства штамма определяли методом агаровых блоков (40). В расплавленную и остуженную до $40{ }^{\circ} \mathrm{C}$ среду КДА вносили суспензию конидий фитопатогенных грибов $\left(10^{8} \mathrm{KOE} / \mathrm{Mл}\right)$ из расчета 1 мл/100 мл среды и разливали в чашки Петри. Целлюлолитические бактерии выращивали на среде Гетчинсона в течение 5 сут при $28{ }^{\circ} \mathrm{C}$, затем из растущей культуры буром (диаметр 7 мм) вырезали блоки, переносили их на чашки Петри, предварительно засеянные культурами фитопатогенных грибов, и оставляли на 72 ч при $28^{\circ} \mathrm{C}$. Контролем служили блоки, вырезанные из чистых сред. Об антифунгальной активности судили по диаметру зоны подавления роста грибов.

Биосовместимость штаммов ЭМ-ассоциации изучали методом перпендикулярных штрихов (41).

Для оценки ростостимулирующей способности разработанной ЭМассоциации входящие в нее штаммы бактерий выращивали отдельно на элективных средах: целлюлолитические бактерии С-82/3 - на среде Гетчинсона, азотфиксирующие - на среде Эшби, фосфатмобилизующие на среде Муромцева $\left(28^{\circ} \mathrm{C}\right.$, на шейкере при 180 об/мин). После этого полученные суспензии бактерий с титром $1 \times 10^{7}$ кл/мл смешивали в соотношении 1:1:1. Семена сахарной свеклы сорта Айсултан инокулировали штаммом С-82/3 или ЭМ-ассоциацией, содержащей все три штамма. Титр суспензий штамма и ассоциации составлял $1 \times 10^{7}$ кл/мл, обработка семян проводилась в течение 2 ч при $23{ }^{\circ} \mathrm{C}$. Затем семена высевали в сосуды с 300 г почвы. Отрицательным контролем были семена, обработанные стерильной водой (42).

Субстратом для выращивания сахарной свеклы служила почва, собранная на полях фермерского хозяйства «Кайынды» (Жамбылская обл., 
Республика Казахстан). Тип почвы - серозем обыкновенный с содержанием гумуса $1,2 \%$, легкогидролизуемого азота - 36,6 мг/кг, подвижного фосфора - 16,4 мг/кг, подвижного калия - 342,5 мг/кг почвы. Через 30 сут измеряли длину стеблей и корней у растений. Эксперименты проводили в климатической камере для выращивания растений (Constant Climate Chamber HPP750, «Memmert GmbH + Co. KG», Германия). Дневной режим 12 ч, температура $24-26^{\circ} \mathrm{C}$, холодный белый свет $6500 \mathrm{~K}$, теплый свет 2700 $\mathrm{K}$; ночной режим - 11 ч, $17-19{ }^{\circ} \mathrm{C}$; автоматическая регулировка влажности (от 60 до $75 \%$ ). Повторность опытов 3-кратная (по 10 растений на повторность).

В полевых условиях ЭМ-ассоциацию, состоящую из трех штаммов бактерий (Bacillus megaterium, Azotobacter chroococcum и Bacillus sp. C-82/3), тестировали в течение 2 лет (2017-2018 годы) на полях фермерского хозяйства «Кайынды». Почва - серозем обыкновенный с содержанием гумуса 1,2-1,5 \%, легкогидролизуемого азота - 34,6 мг/кг почвы, подвижного фосфора - 14,0 мг/кг, подвижного калия - 350 мг/кг почвы. Предшественник - сахарная свекла. Повторность опытов 3-кратная, размещение вариантов систематическое. Семена обрабатывали ЭМ-ассоциацией с титром бактериальной суспензии $1 \times 10^{7}$ кл/мл из расчета 50 мл суспензии на 1 кг семян с увлажнением (расход воды 1 л/кг). Длительность обработки составляла 2 ч. Положительным контролем служили семена, обработанные химическими препаратами ТМТД 80 \% («Август», Россия) и Скор® (Score ${ }^{\circledR}$, «Syngenta AG», Швейцария) в количестве соответственно 6,0 кг/т и 0,4 л/га (эти фунгициды рекомендованы к применению в Казахстане для защиты сахарной свеклы от семенных и почвенных грибных инфекций). Отрицательным контролем служили необработанные семена. В опытах применяли общепринятую для указанной зоны земледелия агротехнику выращивания свеклы. Все опыты проводили в 3-5-кратной повторности. Всхожесть, пораженность корневыми инфекциями, урожайность, сахаристость и сбор сахара оценивали общепринятыми методами.

Статистическую обработку результатов осуществляли с использованием пакета программ STATISTICA 10.0 (StatSoft Inc.», США) (43). В таблицах и на рисунках представлены средние значения $(M)$ и их стандартные отклонения $( \pm \mathrm{SD})$ при $\mathrm{p} \leq 0,05$.

Pезультаты. Бактерии рода Bacillus обитают в ризосфере растений (44) и известны как продуценты различных метаболитов. Наиболее важные биологически активные вещества, синтезируемые этими бактериями, пептиды, липопептиды, поликетидные соединения, бактериоцины и сидерофоры (45). Также представители рода Bacillus характеризуются антагонистической активностью в отношении патогенов растений $(46,47)$ и оказывают ростостимулирующее влияние на сельскохозяйственные культуры $(38,48)$. Исследуемый штамм бактерий C-82/3 был отнесен к роду Bacillus, и предполагалось, что он обладает свойствами, присущими этому роду. Кроме того, целлюлолитические бактерии проявляют высокую антифунгальную активность по отношению к грибным фитопатогенам, вызывающим болезни агрокультур $(49,50)$. В наших опытах при лабораторной оценке антифунгальной активности штамма C-82/3 диаметр зоны подавления роста тест-культур составил $28,9 \pm 0,2$ мм для $F$. oxysporum, $38,2 \pm 0,3$ мм для

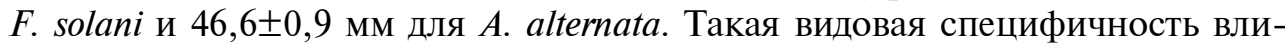
яния бактерий на фитопатогенные грибы согласуется с результатами, полученными другими авторами $(22,24)$.

Созданная нами ранее ассоциация, состоящая из штаммов азот- 
фиксирующих бактерий $A z$. chroococcum и фосфатмобилизующих бактерий B. megaterium, влияла на урожайность сахарной свеклы в полевых условиях. Это связано с тем, что штаммы, входящие в состав ассоциации улучшают азотное и фосфорное питание растений (данные не приведены). Однако ассоциация не обладала антифунгальной активностью по отношению к возбудителям корневых гнилей. Для биоконтроля фитопатогенов в состав ассоциации необходимо было включить бактерии-антагонисты.

Эффективность ассоциации определяется совокупностью биологических свойств штаммов, входящих в ее состав $(51,52)$. При разработке ЭМ-ассоциаций очень важно учитывать возможность сочетания в них штаммов. Главным показателем при создании ассоциации становится биосовместимость, то есть наличие или отсутствие антагонизма между штаммами-партнерами.

A

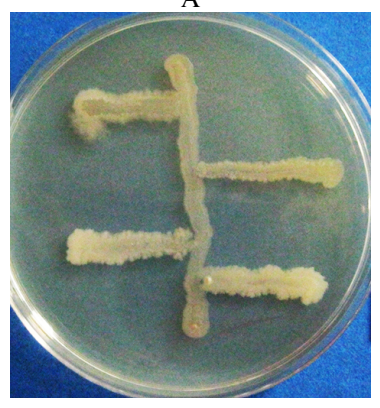

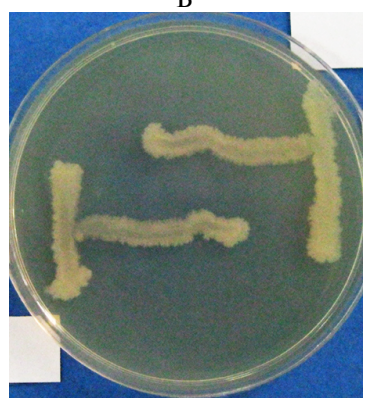

Рис. 1. Биосовместимость штаммов фосфатмобилизующих бактерий Bacillus megaterium (А; горизонтальные штрихи), азотфиксирующих бактерий Azotobacter chroococcum (Б; горизонтальные штрихи), входящих в состав ассоциации агрономически эффективных микроорганизмов, предназначенной для применения на сахарной свекле, и целлюлолитических бактерий Bacillus sp. C82/3 (А, Б; вертикальные штрихи).

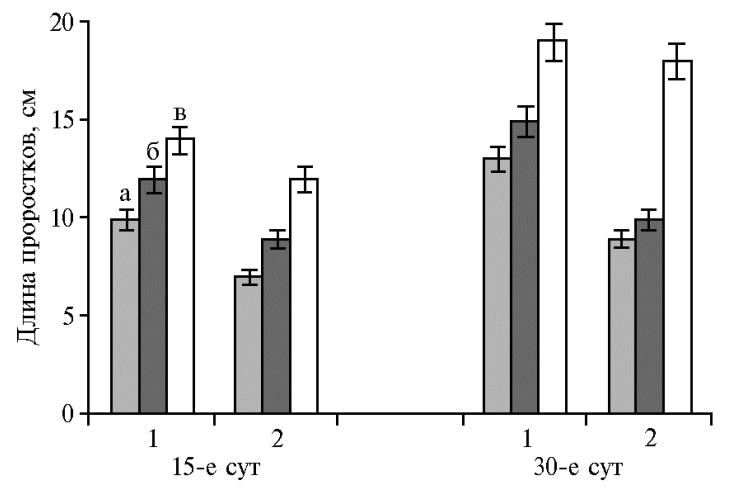

Рис. 2. Развитие стеблей (1) и корней (2) у проростков сахарной свеклы (Beta vulgaris L.) сорта Айсултан при выращивании в условиях климатической камеры в зависимости от предпосевной обработки семян: а - контроль (без обработки), б - обработка Bacillus sp. C$82 / 3$, в - обработка ЭМ-ассоциацией, состоящей из штаммов Bacillus megaterium, Azotobacter chroococcum и Bacillus sp. C-82/3. собностью к синтезу биологически активных веществ $(28,29)$. В ряде работ указывается, что за счет биосинтеза этих веществ бактерии рода Bacillus способны стимулировать развитие растений $(55,56)$.

Для оценки биосовместимости штаммов, входящих в состав ассоциации, и штамма С-82/3, мы использовали метод перпендикулярных штрихов (41). Было установлено, что штаммы азотфиксирующих, фосфатмобилизующих и целлюлолитических бактерий C-82/3 не подавляли рост и развитие друг друга (рис. 1), то есть взаимоотношение между ними характеризовались отсутствием антагонизма. Полученный результат свидетельствовал о возможности включения штамма C-82/3 в состав ЭМ-ассоциации. Наличие биосовместимости между исследованными штаммами бактерий можно объяснить тем, что при сосуществовании в почве эти физиологические группы не конкурируют за источники питания (53). В природных условиях они не становятся антагонистами, то есть не синтезируют вторичных метаболитов, используя которые могут отрицательно влиять на рост и развитие друг друга (54).

Хорошо известно, что представители рода Bacillus доминируют в ризосфере растений (44). Они обладают высокой устойчивостью к внешним факторам среды и спо- 
В климатической камере при выращивании растений свеклы из семян, обработанных штаммом C-82/3 и ЭМ-ассоциацией, включающей три штамма бактерий, было установлено, что они обладали ростостимулирующими свойствами (рис. 2). Так, средняя длина стеблей при обработке штаммом C-82/3 увеличилась в $1,2 \pm 0,1$, корней - в $1,1 \pm 0,1$ раза по сравнению с контролем ( $\leq 0,05)$; при применении ЭМ-ассоциации показатели увеличивались соответственно в $1,5 \pm 0,1$ и $2,0 \pm 0,3$ раза (p $\leq 0,05)$. Предпосевная обработка семян штаммом С-82/3 и ЭМ-ассоциацией также

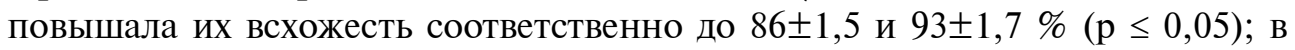
контроле всхожесть семян составляла $80 \pm 1,3 \%(\mathrm{p} \leq 0,05)$. В лабораторных тестах мы использовали семена сахарной свеклы сорта Айсултан, рекомендованного к возделыванию в юго-восточном регионе Казахстана.

Как уже отмечалось, ростостимулирующая способность ЭМ-ассоциации была обусловлена тем, что входящие в ее состав штаммы азотфиксирующих бактерий $A z$. chroococcum и фосфатмобилизующих бактерий B. megaterium улучшают азотное и фосфорное питание растений; штамм Bacillus sp. C-82/3, возможно, синтезирует витамины, аминокислоты и фитогормоны. Способность бациллярного штамма С-82/3 синтезировать вторичные метаболиты, стимулирующие рост растений, согласуется с данными литературы $(28,55,56)$. Кроме того, штамм C-82/3 образует ферменты целлюлазы, которые могут частично разрушать твердую оболочку семян и за счет этого повышать их всхожесть (39).

Полевые испытания показали высокую эффективность ЭМ-ассоциации, состоящей из штаммов B. megaterium, Az. chroococcum и Bacillus sp. C$82 / 3$, в качестве агента биоконтроля фитопатогенных грибов родов $F u$ sarium и Alternaria, вызывающих корневые гнили сахарной свеклы. Фитопатогены поражали растения в течение всего вегетационного периода, начиная с фазы 1-й пары листьев и до уборки корнеплодов. Первые признаки корневой гнили появлялись уже в конце мая-начале июня, их распространение достигало максимума к сбору урожая (конец сентябряначало октября). Применение ЭМ-ассоциации снижало пораженность всходов сахарной свеклы в 2,3 раза, корнеплодов - в 3,0 раза по сравнению с контролем (табл. 1).

1. Всхожесть и пораженность корневыми инфекциями у проростков сахарной свеклы (Beta vulgaris L.) сорта Айсултан в полевых условиях в зависимости от предпосевной обработки семян $(M \pm \mathrm{SD}$, фермерское хозяйство «Кайынды», Жамбылская обл., Республика Казахстан, 2017-2018 годы)

\begin{tabular}{|c|c|c|c|}
\hline \multirow{2}{*}{ Вариант } & \multirow{2}{*}{$\begin{array}{l}\text { Густота всхо- } \\
\text { Дов, шт } / \mathrm{M}^{2}\end{array}$} & \multicolumn{2}{|c|}{ Корневые инфекции, \% } \\
\hline & & «черная ножка» проростков & фузариозные гнили корней \\
\hline ЭМ-ассоциация & $74,3 \pm 2,4^{*}$ & $17,2 \pm 1,1^{*}$ & $7,1 \pm 0,9 *$ \\
\hline ТМТД + Скор® (эталон) & $72,7 \pm 2,1^{*}$ & $18,5 \pm 1,4^{*}$ & $10,0 \pm 0,8$ \\
\hline Контроль (без обработки) & $68,2 \pm 1,9$ & $40,3 \pm 2,3$ & $21,6 \pm 1,3$ \\
\hline \multicolumn{4}{|c|}{$\begin{array}{l}\text { П р и м е ч а н и е. В состав ЭМ-ассоциации входили бактерии Bacillus megaterium, Azotobacter chroococcum } \\
\text { и Bacillus sp. С-82/3. В варианте с химическими обработками применяли препараты ТМТД } 80 \text { \% } \\
\text { («Август», Россия) и Скор® (Score } 囚 \text {, «Syngenta AG», Швейцария) в дозе соответственно 6,0 кг/т и } 0,4 \text { л/га. } \\
\text { * Различия с контролем статистически значимы при р < } 0,05 .\end{array}$} \\
\hline
\end{tabular}

Также микроорганизмы положительно влияли на продуктивность и качественные показатели корнеплодов (табл. 2). При применении ЭМ-ассоциации урожайность сахарной свеклы по сравнению с контролем увеличилась на $34 \pm 2,3$ ц/га, или на $12,6 \pm 1,1 \%$ ( $\leq 0,05)$, сахаристость корнеплодов - на 4,0 \%, сбор сахара - на 9,0 ц/га. Следует отметить, что обработка семян ассоциацией существенно не влияла на биомассу надземной части сахарной свеклы (данные не приведены), что особенно важно 
для культур, у которых для производственных целей используется корневая часть растений (21).

2. Урожайность и качественные показатели корнеплодов у сахарной свеклы (Beta vulgaris L.) сорта Айсултан в полевых условиях в зависимости от предпосевной обработки семян $(M \pm \mathrm{SD}$, фермерское хозяйство «Кайынды», Жамбылская обл., Республика Казахстан, 2017-2018 годы)

\begin{tabular}{|c|c|c|c|c|c|}
\hline \multirow{2}{*}{ Вариант } & \multirow{2}{*}{$\begin{array}{l}\text { Урожайность, } \\
\text { ц/га }\end{array}$} & \multicolumn{2}{|c|}{ Прибавка к контролю } & \multirow{2}{*}{$\begin{array}{l}\text { Сахаристость, } \\
\%\end{array}$} & \multirow{2}{*}{$\begin{array}{l}\text { Сбор сахара, } \\
\text { ц/га }\end{array}$} \\
\hline & & ц/га & $\%$ & & \\
\hline ЭМ-ассоциация & $304,0 \pm 10,4^{*}$ & $34,0 \pm 2,3^{*}$ & $12,6 \pm 1,1^{*}$ & $14,9 \pm 1,1$ & $58,0 \pm 2,1^{*}$ \\
\hline ТМТД + Скор® (эталон) & $282,0 \pm 9,8^{*}$ & $12,0 \pm 0,9^{*}$ & $7,1 \pm 0,2$ & & \\
\hline Контроль (без обработки) & $270,0 \pm 7,9$ & & & $11,2 \pm 0,5$ & $48,9 \pm 1,5$ \\
\hline \multicolumn{6}{|c|}{$\begin{array}{l}\text { П р и м е ч а н и е. В состав ЭМ-ассоциации входили бактерии Bacillus megaterium, Azotobacter chroococcum } \\
\text { и Bacillus sp. С-82/3. В варианте с химическими обработками применяли препараты ТМТД } 80 \% \\
\text { («Август», Россия) и Скор }{ }^{\circledR} \text { (Score } 囚 \text {, «Sуngenta AG», Швейцария) в дозе соответственно } 6,0 \text { кг/т и } 0,4 \text { л/га. } \\
\text { * Различия с контролем статистически значимы при р <0,05. }\end{array}$} \\
\hline
\end{tabular}

Полученные результаты согласуются с исследованиями, в которых отмечается повышение продуктивности сельскохозяйственных культур при использовании эффективных микроорганизмов $(57,58)$. Во многих работах была установлена их ростостимулирующая активность $(27,48,59)$. Однако ранее эффективные микроорганизмы применялись только для биоконтроля грибных патогенов $(46,60)$ либо стимуляции роста культур (42, 55). Также использовалась способность этих микроорганизмов синтезировать биологически активные метаболиты $(47,61)$. Созданная нами ЭМассоциация характеризуется комплексным действием: улучшает азотное и фосфорное питание растений, обладает антифунгальной активностью, продуцирует биологически активные вещества, стимулирует рост и развитие растений сахарной свеклы, что способствует повышению ее продуктивности и сахаристости корнеплодов.

Таким образом, установлена высокая антифунгальная активность нового штамма целлюлолитических бактерий Bacillus sp. C-82/3 по отношению к фитопатогенным грибам, вызывающим корневые гнили сахарной свеклы. Показана его биосовместимость со штаммами азотфиксирующих и фосфатмобилизующих бактерий, что позволило создать новую ассоциацию эффективных микроорганизмов (ЭМ-ассоциацию), обладающую антифунгальной активностью и положительно влияющую на показатели продуктивности и качества у сахарной свеклы. В условиях климатической камеры доказана способность штамма и ЭМ-ассоциации повышать всхожесть семян и стимулировать развитие растений сахарной свеклы. Проведенные 2-летние полевые испытания ЭМ-ассоциации на юго-востоке Казахстана показали возможность ее интродукции в почвенные биоценозы с целью биоконтроля корневых гнилей, вызванных грибами родов Fusarium и Alternaria. Применение ЭМ-ассоциации снизило пораженность всходов грибными инфекциями в 2,3 раза, уменьшило гниль корнеплодов в 3,0 раза, при этом урожайность возросла на 12,6 \%, а сбор сахара - на 9,0 \%. Кроме положительного влияния на урожайность сахарной свеклы, ЭМ-ассоциация обеспечила получение корнеплодов с повышенным содержанием сахарозы. Доказанная высокая эффективность ЭМ-ассоциации свидетельствует о целесообразности ее использования в качестве агента биоконтроля в растениеводстве России, Казахстана и других сопредельных стран со схожими природно-климатическими условиями.

\footnotetext{
ТОО Научно-производственный центр микробиологии и вирусологии,

050010 Республика Казахстан, г. Алматы, ул. Богенбай батыра, 105, e-mail: iesmirnova@mail.ru $₫$, a.sadanov@inbox.ru
}

Поступила в редакцию 20 июня 2019 года 


\title{
CELLULOLYTIC BACTERIA AND ASSOCIATION OF EFFECTIVE MICROORGANISMS FOR BIOCONTROL OF ROOT ROT INFECTIONS IN SUGAR BEET (Beta vulgaris L.)
}

\section{I.E Smirnova, A.K. Sadanov}

\author{
LP Scientific Production Center of Microbiology and Virology, 105, Bogenbai Batyr str., Almaty, 050010 Kazakhstan, \\ e-mail: iesmirnova@mail.ru ( $\square$ corresponding author), a.sadanov@inbox.ru \\ ORCID: \\ Smirnova I.E orcid.org/0000-0001-5854-1529 \\ The authors declare no conflict of interests \\ Acknowledgements: \\ Supported financially by the Kazakhstan Ministry of Education and Science (grant project No. AP05131526) \\ Received June 20, 2019 \\ Sadanov A.K. orcid.org/0000-0002-2593-6302 \\ doi: 10.15389/agrobiology.2019.5.1041eng
}

\begin{abstract}
At the present time, many farmers growing sugar beet (Beta vulgaris L.) reduce application of fertilizers and crop rotations, which leads to accumulation of phytopathogens. The main pathogens of sugar beet causing root rot are fungi from genera Fusarium Lk.:Fr. and Alternaria (Fr.) Keissi. Chemical fungicides are used worldwide to protect crops but plant pathogenic fungi acquire resistance against conventional chemicals. Therefore, the biological methods of plant protection are relevant. In our previous works, we have designed the association of effective microorganisms (EM Association) which includes nitrogen-fixing Azotobacter chroococcum and phosphate-mobilizing Bacillus megaterium bacteria. This association can increase the productivity of sugar beet plants but does not possess antifungal activity against sugar beet root rot. Cellulolytic bacteria are an important component of microbiocenoses. They play a significant role in soil processes; their number is an indicator of soil fertility and ecological quality. Colonizing rhizosphere of plants, they synthesize bioactive substances, including antifungal metabolites. Among cellulolytic bacteria there are active antagonists of fungal root rot causative agents. In this paper we present our research findings on the antifungal properties of a new cellulolytic strain Bacillus sp. C- $82 / 3$ and the first effective association of this strain with nitrogen-fixing and phosphate-mobilizing bacteria which promotes sugar beet growth and yield. The goal of the research was to evaluate antifungal activity of the novel strain of cellulolytic bacteria Bacillus sp. C-82/3 isolated from soil rhizosphere of healthy sugar beet plants in the SouthEast of Kazakhstan (Zhambyl region), to enrich the EM association developed with this strain, and to assess the plant growth promoting activity of the improved EM Association and its ability to biocontrol rot root infections under field condition. Antifungal activity was determined in agar block diffusion tests against Alternaria alternata (Fr.) Keissl, Fusarium solani (Mart.) Sacc. and F. oxysporum Schlecht. The strain was grown on the Hutchinson's medium $\left(1.0 \mathrm{~g} / 1 \mathrm{~K}_{2} \mathrm{HPO}_{4}, 0.1 \mathrm{~g} / \mathrm{l}\right.$ $\mathrm{CaCl}_{2}, 0.3 \mathrm{~g} / 1 \mathrm{MgSO}_{4}, 2.5 \mathrm{~g} / 1 \mathrm{NaNO}_{3}, 1.0 \mathrm{~g} / 1 \mathrm{NaCl}, 0.01 \mathrm{~g} / \mathrm{l} \mathrm{FeCl}_{3}, 20 \mathrm{~g} / \mathrm{l}$ wheat straw, $5,0 \mathrm{~g} / 1$ yeast extract; $\mathrm{pH}$ 7.0). Blocks with growing culture were cut out, and put on Petri dishes with potatodextrose agar earlier inoculated with fungi, and cultured at $28{ }^{\circ} \mathrm{C}$ for 3 days. Antifungal activity was assessed by the diameter of growth inhibition zone. To study the plant growth promoting activity of the EM association with Bacillus sp. C-82/3, the cv. Aisultan seeds were treated with the bacterial suspension $\left(10^{7}\right.$ cells $\left./ \mathrm{ml}\right)$ at $23{ }^{\circ} \mathrm{C}$ for 2 hours. The stem and root length measured in the inoculated seedling after 30-day growing in a climatic chamber (Constant Climate Chamber HPP750, Memmert GmbH + Co. KG, Germany) were compared to the control. Field tests were conducted in the South-East of Kazakhstan (Zhambyl region, Kaiyndy farm) in 2017-2018. The results of lab screening showed high antifungal activity of the novel strain Bacillus sp. C-82/3 with the mean inhibition halos of $28.9 \pm 0.2 \mathrm{~mm}$ for $F$. oxysporum, $38.2 \pm 0.3 \mathrm{~mm}$ for $F$. solani, and $46.6 \pm 0.9 \mathrm{~mm}$ for A. alternate. The improved EM Association which includes three strains (Bacillus megaterium, Azotobacter chroococcum and Bacillus sp. C-82/3) was characterized by high growth-promoting activity. Germination of the inoculated seeds was 7-16\% higher, and stem and root length increased 1.2-1.5fold and 1.1-2.0-fold, respectively, as compared to control ( $\mathrm{p} \leq 0.05)$. We also revealed the high ability of the EM Association containing Bacillus sp. C-82/3 strain to suppress sugar beet root rot pathogens in soil biocenosis. Seed inoculation with the microbial association decreased the damage to seedlings 2.3 times, to roots 3.0 times. The yield of sugar beet was $34.2 \pm 2.3 \mathrm{c} /$ ha higher compared to control $(\mathrm{p} \leq 0.05)$. Thus, our data are the first evidence that the EM Association with Bacillus sp. C-82/3, a new cellulolytic strain with high antifungal activity that we have detected, is effective against root rot infection and promotes an increase in sugar beet yield under field condition.
\end{abstract}

Keywords: Beta vulgaris L., sugar beet, biological control, cellulolytic bacteria, effective microorganisms association, antifungal activity, growth-promoting activity, phytopathogenic fungi, root rot. 


\section{R E F E R E N C E S}

1. Solomon S., Quirk R.G., Shukla S.K. Green management for sustainable sugar industry. Sugar Tech., 2019, 21(2): 183-185 (doi: 10.1007/s12355-019-00711-2).

2. Tereshchenkova I.A. Vestnik Belorusskoi gosudarstvennoi sel'skokhozyaistvennoi akademii, 2015, 4: 11-14 (in Russ.).

3. Kirillov N.A., Volkov A.I., Prokhorova L.H. Sakharnaya svekla, 2013, 1: 23-27 (in Russ.).

4. Paramasivan M., Chandrasekaran A., Mohan S., Muthukrishnan N. Ecological management of tropical sugar beet (TSB) root rot by rhizosphere Trichoderma species. Archives of Phytopathology and Plant Protection, 2014, 47(13): 1629-1644 (doi: 10.1080/03235408.2013.853460).

5. Mahmoud A.F. Suppression of sugar beet damping-off caused by Rhizoctonia solani using bacterial and fungal antagonists. Archives of Phytopathology and Plant Protection, 2016, 49(19-20): 575-585 (doi: 10.1080/03235408.2016.1245052).

6. Maui A.A. Novosti nauki Kazakhstana, 2014, 2(120): 63-70 (in Russ.).

7. Merzaliev K., Kul'keev E.E., Al'dekov N.A., Amanova K.S. Vestnik sel'skokhozyaistvennykh nauk Kazakhstana, 2016, 1-2: 21-25 (in Russ.).

8. Abd-El-Khair H., Abd-El-Fattah A.I., El-Nagdi W.M.A. Evaluation of five sugar beet varieties for root-knot nematode and root-rot fungal infection. Arch. Phytopath. Plant Prot., 2013, 46(18): 2163-2173 (doi: 10.1080/03235408.2013.785660).

9. Mahmoud A.F. Occurrence of Fusarium wilt on summer squash caused by Fusarium oxysporum in Assiut, Egypt. Journal of Phytopathology and Pest Management, 2016, 3(1): 34-45.

10. Mahmoud A.F. Evaluation of certain antagonistic fungal species for biological control of faba bean wilt disease incited by Fusarium oxysporum. Journal of Phytopathology and Pest Management, 2016, 3(2): 1-14.

11. Maui A.A., Ismukhambetov Zh.D. Kompleksnaya sistema zashchity posevov sakharnoi svekly ot vreditelei, boleznei i sornyakov dlya uslovii yuga i yugo-vostoka Kazakhstana [A comprehensive system for the protection of sugar beet crops from pests, diseases and weeds in the south and southeast Kazakhstan]. Almaty, 2012 (in Russ.).

12. Selivanova G.A. Zemledelie, 2013, 4: 31-37 (in Russ.).

13. Stognienko O.I., Shamin A.A. Zashchita i karantin rastenii, 2014, 8: 12-15 (in Russ.).

14. Shamin A.A., Stognienko O.I., Borotov O.K. Zemledelie, 2013, 4: 35-38 (in Russ.).

15. Strausbaugh C.A., Gillen A.M. Sugar beet root rot at harvest in the US Intermountain West. Canadian Journal of Plant Pathology, 2009, 31(2): 232-240 (doi: 10.1080/07060660909507596).

16. Karimi E., Sadeghi A., Dahaji P.A., Dalvand Y., Omidvari M., Nezhad M.K. Biocontrol activity of salt tolerant Streptomyces isolates against phytopathogens causing root rot of sugar beet. $\mathrm{Bi}$ ocontrol Science and Technology, 2012, 22(3): 333-349 (doi: 10.1080/09583157.2012.658552).

17. Webb K.M., Brenner T., Jacobsen B.J. Temperature effects on the interactions of sugar beet with Fusarium yellows caused by Fusarium oxysporum f. sp. betae. Canadian Journal of Plant Pathology, 2015, 37(3): 353-362 (doi: 10.1080/07060661.2015.1071283).

18. Gossen B.D., Carisse O., Kawchuk L.M., van der Heyden H., McDonald M.R. Recent changes in fungicide use and the fungicide insensitivity of plant pathogens in Canada. Canadian Journal of Plant Pathology, 2014, 36(3): 327-340 (doi: 10.1080/07060661.2014.925506).

19. Prior R., Mittelbach M., Begerow D. Impact of three different fungicides on fungal epi- and endophytic communities of common bean (Phaseolus vulgaris) and broad bean (Vicia faba). Journal of Environmental Science and Health, Part B, 2017, 52(6): 376-386 (doi: 10.1080/03601234.2017.1292093).

20. Wedge D.E., Surry J.K., Kreiser B., Curry A., Abril M., Smith B.J. Fungicide resistance profiles for 13 Botrytis cinerea isolates from strawberry in Southeastern Louisiana. International Journal of Fruit Science, 2013, 13(4): 413-429 (doi: 10.1080/15538362.2013.789253).

21. Shabaev V.P. Sel'skokhozyaistvennaya biologiya [Agricultural Biology], 2005, 3: 55-61 (in Russ.).

22. Trenozhnikova L.P., Balgimbaeva A.S., Ultanbekova G.D., Galimbaeva R.Sh. Antifungal activity against pathogens of cereals and characterization of antibiotics of Streptomyces sp. strain K541 isolated from extreme ecosystems in Kazakhstan. Agricultural Biology [Sel'skokhozyaistvennaya biologiya], 2018, 53(1): 96-102 (doi: 10.15389/agrobiology.2018.1.96rng).

23. Abeer H., Asma A.H., Allah A., Qarawi A., Shalawi A., Dilfuza E. Impact of plant growthpromoting Bacillus subtilis on growth and physiological parameters of Bassia indica (Indian Bassia) grown under salt stress. Pakistan Journal of Botany, 2015, 47(5): 1735-1741.

24. Bjelić D., Marinković J., Tintor B., Mrkovački N. Antifungal and plant growth promoting activities of indigenous rhizobacteria isolated from maize (Zea mays L.) rhizosphere. Communications in Soil Science and Plant Analysis, 2018, 49(1): 88-98 (doi: 10.1080/00103624.2017.1421650).

25. Talaat N.B. Effective microorganisms improve growth performance and modulate the ROSscavenging system in common bean (Phaseolus vulgaris L.) plants exposed to salinity stress. $J$. Plant Growth Regul., 2015, 34(1): 35-46 (doi: 10.1007/s00344-014-9440-2).

26. Bzdyk R.M., Olchowik J., Studnicki M., Oszako T., Sikora K., Szmidla H., Hilszczańska D. The impact of effective microorganisms (EM) and organic and mineral fertilizers on the growth 
and mycorrhizal colonization of Fagus sylvatica and Quercus robur seedlings in a bare-root nursery experiment. Forests, 2018, 9: 597-610 (doi: 10.3390/f9100597).

27. $\mathrm{Hu}$ C., Qi Y. Long-term effective microorganisms application promote growth and increase yields and nutrition of wheat in China. European Journal of Agronomy, 2013, 46: 63-67 (doi: 10.1016/j.eja.2012.12.003).

28. Ndona R.K., Friede J.K., Spornberger A., Jezik K. Effective microorganisms (EM): an effective plant strengthening agent for tomatoes in protected cultivation. Biological Agriculture \& Horticulture, 2011, 27(2): 189-204 (doi: 10.1080/01448765.2011.9756647).

29. Mayer J., Scheid S., Widmer F., Fliebach A., Oberholzer H.-R. How effective are effective microorganisms (EM). Results from a field study in temperate climate. Applied Soil Ecology, 2010, 46(2): 230-239 (doi: 10.1016/j.apsoil.2010.08.007).

30. Kleiber T., Starzyk J., Bosiacki M. Effect of nutrient solution, effective microorganisms (EMA), and assimilation illumination of plants on the induction of the growth of lettuce (Lactuca sativa L.) in hydroponic cultivation. Acta Agrobot., 2013, 66(1): 27-38 (doi: 10.5586/aa.2013.004).

31. Chudasama K.S., Thaker V.S. Screening of potential antimicrobial compounds against Xanthomonas campestris from 100 essential oils of aromatic plants used in India: an ecofriendly approach. Archives of Phytopathology and Plant Protection, 2012, 45(7): 783-795 (doi: 10.1080/03235408.2011.595967).

32. Zameer M., Zahid H., Tabassum B., Ali Q., Nasir I.A., Saleem M., Butt S.J. PGPR potentially improve growth of tomato plants in salt-stressed environment. Turkish Journal of Agriculture Food Science and Technology, 2016, 4(6): 455-463 (doi: 10.24925/turjaf.v4i6.455-463.614).

33. Saini J.K., Saini R., Tewari L. Simultaneous isolation and screening of cellulolytic bacteria: selection of efficient medium. Journal of Pure and Applied Microbiology, 2012, 6(3): 1339-1344.

34. Zhao Y.-N., Zhang Y.-Q., Du H.-X., Wang Y.-H., Zhang L.-M., Shi X.-J. Carbon sequestration and soil microbes in purple paddy soil as affected by long-term fertilization. Toxicological \& Environmental Chemistry, 2015, 97(3-4): 464-476 (doi: 10.1080/02772248.2015.1050200).

35. Shmidt K.N., Khudaigulov G.G. Vestnik YuUrGU. Seriya Pishchevye i biotekhnologii, 2016, 4(4): 54-63 (in Russ.).

36. Naplekova N.N. Metabolity aerobnykh tsellyulozoliticheskikh mikroorganizmov $i$ ikh rol' $v$ pochvakh [Metabolites of aerobic cellulolytic microorganisms and their role in soils]. Novosibirsk, 2010 (in Russ.).

37. Ang S.K., Yahya A., Aziz S.A., Salleh M.M. Isolation, screening, and identification of potential cellulolytic and xylanolytic producers for biodegradation of untreated oil palm trunk and its application in saccharification of lemongrass leaves. Preparative Biochemistry and Biotechnology, 2015, 45(3): 279-305 (doi: 10.1080/10826068.2014.923443).

38. Smirnova I.E. Mikologiya i fitopatologiya, 2004, 38(2): 89-93 (in Russ.).

39. Smirnova I.E., Sadanov A.K., Galimbaeva R.Sh. Biological method for improving germinating and productivity of melilot. In: Recent trends in PGPR research for sustainable crop productivity. M.S. Reddy, R.I. Ilao, P.S. Faylon (eds). Jodhpur-Delhi-Germany, 2016: 21-28.

40. Egorov N.S. Osnovy ucheniya ob antibiotikakh [Basics of the antibiotics doctrine]. Moscow, 2004 (in Russ.).

41. Semenov A.V., Sgibnev A.V., Cherkasov S.V., Bukharin O.V. Byulleten' eksperimental'noi biologii $i$ meditsiny, 2007, 144: 702-705 (in Russ.).

42. Vessey J.K. Plant growth promoting rhizobacteria as biofertilizers. Plant Soil, 2003, 255(2): 571586 (doi: 10.1023/A:1026037216893).

43. Borovikov V.P. Populyarnoe vvedenie $v$ sovremennyi analiz dannykh $v$ sisteme STATISTICA [A popular introduction to modern data analysis in the STATISTICA system]. Moscow, 2013 (in Russ.).

44. Felske A.D.M. Ecology of Bacillus species in soil. In: Bacterial spore formers: probiotics and emerging applications. E. Ricca, A.O. Henriques, S.M. Cutting (eds.). Horizon Bioscience, Norfolk, 2004: 35-44.

45. Fira D., Dimkić I., Berić T., Lozo J., Stanković S. Biological control of plant pathogens by Bacillus species. Journal of Biotechnology, 2018, 285: 44-55 (doi: 10.1016/j.jbiotec.2018.07.044).

46. Cao Y., Xu Z., Ling N., Yuan Y., Yang X., Chen L., Shen B., Shen Q. Isolation and identification of lipopeptides produced by B. subtilis SQR 9 for suppressing Fusarium wilt of cucumber. Scientia Horticulturae, 2012, 135: 32-39 (doi: 10.1016/j.scienta.2011.12.002).

47. Guo Q., Dong W., Li S., Lu X., Wang P., Zhang X., Wang Y., Ma P. Fengycin produced by Bacillus subtilis NCD-2 plays a major role in biocontrol of cotton seedling damping-off disease. Microbiological Research, 2014, 169(7-8): 533-540 (doi: 10.1016/j.micres.2013.12.001).

48. Pérez-García A., Romero D., de Vicente A. Plant protection and growth stimulation by microorganisms: biotechnological applications of Bacilli in agriculture. Current Opinion in Biotechnology, 2011, 22(2): 187-193 (doi: 10.1016/j.copbio.2010.12.003).

49. Hinarejos E., Castellano M., Rodrigo I., Bellés J.M., Conejero V., López-Gresa M.P., Lisón P. Bacillus subtilis IAB/BS03 as a potential biological control agent. Eur. J. Plant Pathol., 2016, 146(3): 597-608 (doi: 10.1007/s10658-016-0945-3). 
50. Smirnova I.E., Koishibaev M.K., Talip Zh.Sh. Novosti nauki Kazakhstana, 2008, 2: 124-126 (in Russ.).

51. Dardanelli M.S., De Córdoba F.J.F., Espuny M.R., Carvajal M.A.R., Díaz M.E.S., Serrano A.M.G., Okon Y., Megías M. Effect of Azospirillum brasilense coinoculated with Rhizobium on Phaseolus vulgaris flavonoids and Nod factor production under salt stress. Soil Biology and Biochemistry, 2008, 40(11): 2713-2721 (doi: 10.1016/j.soilbio.2008.06.016).

52. Askary M., Mostajeran A., Amooaghaei R., Mostajeran M. Influence of the coinoculation Azospirillum brasilense and Rhizobium meliloti plus 2,4-D on grain yield and N, P, K content of Triticum aestivum (cv. Baccros and Mahdavi). American-Eurasian J. Agric. Environ. Sci., 2009, 5(3): 296-307.

53. Packialakshmi N., Yasotha C. Role of effective microorganism in unfertile soil. Int. J. Phytopharm., 2014, 4(1): 25-27.

54. Gobbetti M., Cagno R.D., De Angelis M. Functional microorganisms for functional food quality. Critical Reviews in Food Science and Nutrition, 2010, 50(8): 716-727 (doi: 10.1080/10408398.2010.499770).

55. Kopteva T.S., Erina N.V. Zaikina I.A. Nauchnyi zhurnal KubGAU, 2015, 114(10): 1-10 (in Russ.).

56. Nautiyal C.S., Srivastava S., Chauhan P.S., Seem K., Mishra A., Sopory S.K. Plant growthpromoting bacteria Bacillus amyloliquefaciens NBRISN13 modulates gene expression profile of leaf and rhizosphere community in rice during salt stress. Plant Physiology and Biochemistry, 2013, 66: 1-9 (doi: 10.1016/j.plaphy.2013.01.020).

57. Iriti M., Scarafoni A., Pierce S., Castorina G., Vitalini S. Soil application of Effective Microorganisms (EM) maintains leaf photosynthetic efficiency, increases seed yield and quality traits of bean (Phaseolus vulgaris L.) plants grown on different substrates. International Journal of Molecular Sciences, 2019, 20(9): 2327-2335 (doi: 10.3390/ijms20092327).

58. Ncube L., Minkeni P.N.S., Brutsch O. Agronomic suitability of effective microorganisms for tomato production. African Journal of Agricultural Research, 2011, 6(3): 650-654.

59. Souza R., Ambrosini A., Passaglia L.M.P. Plant growth-promoting bacteria as inoculants in agricultural soils. Genetics and Molecular Biology, 2015, 38(4): 401-419 (doi: 10.1590/S1415475738420150053).

60. Patkowska E., Konopiński M. Antagonistic activity of selected bacteria occurring in the soil after root chicory cultivation. Plant, Soil and Environment, 2018, 60(7): 320-324 (doi: 10.17221/283/2014-PSE).

61. Singh R., Kumar M, Mittal A., Mehta R.K. Microbial metabolites in nutrition, healthcare and agriculture. 3 Biotech, 2017, 7(1): 4-14 (doi: 10.1007/s13205-016-0586-4). 